\title{
Determination of Longshore Sediment Transport and Modelling of Shoreline Change
}

\author{
H. Anıl Arı Güner, Yalçın Yüksel and Esin Özkan Çevik \\ Yildiz Technical University \\ Turkey
}

\section{Introduction}

\subsection{Longshore sediment transport}

Littoral transport is the movement of sedimentary material in the littoral zone, that is, the zone close to the shoreline. Littoral transport is classified as cross-shore transport or as alongshore transport. Littoral transport results from the interaction of winds, waves, currents, tides, sediments and other phenomena in the littoral zone. Transport can be described by the product of instantaneous concentration and the instantaneous velocity. Generally the sediment transport through a plane of unit width and height equal to the water depth is denoted by,

$$
\mathrm{q}_{\mathrm{s}}=\frac{1}{\mathrm{t}^{\prime}} \int_{0}^{\mathrm{h}+\mathrm{\eta}} \int_{0}^{\mathrm{t}^{\prime}} \mathrm{c}(\mathrm{z}, \mathrm{t}) \mathrm{u}(\mathrm{z}, \mathrm{t}) \mathrm{dtd} \mathrm{z}
$$

where $\mathrm{q}_{\mathrm{s}}$ is the sediment transport rate $\left(\mathrm{m}^{3} / \mathrm{ms}\right), t^{\prime}$ is the integration period $(\mathrm{s}), \mathrm{h}$ is the local water depth $(\mathrm{m}), \eta$ is the instantaneous water surface elevation $(\mathrm{m}), \mathrm{c}(\mathrm{z}, \mathrm{t})$ is the instantaneous concentration of material, $\mathrm{u}(\mathrm{z}, \mathrm{t})$ is the instantaneous velocity component $(\mathrm{m} / \mathrm{s}), \mathrm{z}$ is the elevation above the bed level $(\mathrm{m}), \mathrm{t}$ is the time $(\mathrm{s})$. When waves approach a shoreline at an angle, alongshore sediment transport (also often called littoral transport in some literatures) takes places. Equation (1) for the alongshore sediment transport can therefore be reduced to a much more convenient equation;

$$
\mathrm{q}_{\mathrm{s}}=\frac{1}{\mathrm{t}^{\prime}} \int_{0}^{\mathrm{h}+\mathrm{\eta}} \mathrm{u}(\mathrm{z}) \overline{\mathrm{c}(\mathrm{z})} \mathrm{dz}
$$

where the velocity, $u$, is taken equal to the alongshore velocity, $\mathrm{V}$. This velocity is practically independent of time, because the waves, causing the time dependent velocity component, are assumed to act almost perpendicularly to the coast and thus to the alongshore velocity direction. Because the velocity $\mathrm{u}(\mathrm{z}, \mathrm{t})$ is almost independent of time $[\mathrm{u}(\mathrm{z}, \mathrm{t}) \rightarrow \mathrm{u}(\mathrm{z})]$ the time averaged concentration $\overline{\mathrm{c}(\mathrm{z})}$ can be used instead of the instantaneous concentration $[\mathrm{c}(\mathrm{z}, \mathrm{t})]$. Equation (2) for longshore sediment transport is similar to the sediment transport formulas used for rivers. Principally both types of transport formulas are same, so it is possible to use these transport formulas also for a current alone situation. The methods used for calculating 
the velocity and the concentration, however, are different in each case. The velocity depends on the generating forces and on the bottom shear stress. The bottom shear stress is influenced by the wave action. The sediment concentration along the coast is much higher than in a river because wave action stirs up a lot of material from the bottom and the current transports it (van der Velden, 1989). Alongshore transport has an average net direction parallel to the shoreline. Sediment, moved by alongshore transport, will generally not return to the same area.

When waves break in the surf zone they release momentum, giving rise to a "radiation stress". The cross-shore component of the radiation stress forces water onshore and causes a set-up of the water level, which rise in the onshore direction above the still water level. The water surface slope that produces balances the cross-shore gradient of the shore-normal component of the radiation stress. For waves incident obliquely on the shoreline is also an alongshore component of the radiation stress, whose gradient gives rise to a "longshore current" within (and just outside) the surf zone which is balanced by friction with bed. This in turn drives sediment longshore as a longshore sediment transport.

There are several expressions to calculate the potential velocity of longshore current (current for an infinitely long, strait beach). One commonly used expression is based on LonguetHiggins (1970).

$$
\mathrm{V}_{\mathrm{L}}=20.7 \mathrm{~m} \sqrt{\mathrm{gH}_{\mathrm{b}}} \sin 2 \alpha_{\mathrm{b}}
$$

where $\mathrm{V}_{\mathrm{L}}$ is the longshore current velocity, $\mathrm{m}$ is the beach slope, $\mathrm{H}_{\mathrm{b}}$ is the breaking wave height, $\alpha_{b}$ is the wave breaking angle.

Sediment transport due to the various incident waves from the one end of a beach can then be added up to yield a sediment transport rate to the other end $\left(\mathrm{q}_{\mathrm{t}+}\right)$ ). Similarly the sediment

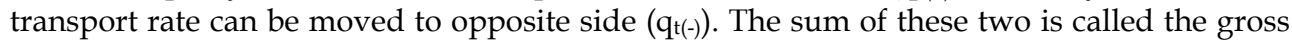
sediment transport rate and the difference is the net sediment transport rate. This net rate has a direction and the terms updrift and down drift are relative to the direction of the net sediment transport (Kamphuis, 2010). This transport process will drive the form of the beaches.

In the past, many researchers have attempted to determine the longshore transport rate. Both $\mathrm{u}(\mathrm{z})$ and $\mathrm{c}(\mathrm{z})$ depend on various parameters (wave characteristics, $\mathrm{H}_{0}$ and $\mathrm{T}$, breaker index, $\gamma$, sediment characteristics, $\mathrm{d}_{50}$, angle of wave incidence, $\theta_{0}$, slope of beach profile, $\mathrm{m}$, bed roughness, $\mathrm{k}_{\mathrm{s}}$ ). The difference between the various solutions is the way in which they take into account the mentioned parameters above. Furthermore the transport formulas are defined differently. Since most coastal sediments are sandy, formulas have generally been developed for sandy beaches. Some longshore sediment transport formulas are discussed in the present chapter which are mostly used longshore sediment transport calculation.

\subsection{Longshore sediment transport formulas}

\section{Bijker formula (1971)}

Bijker formula can calculate sediment transport and the transport distribution through the surf zone. Bijker (1971) developed a formula to calculate the sediment transport as a function of a given wave field and a given alongshore current irrespective of its origin (wave-induced current or tidal current). Bijker formula is based on that transport equals velocity times concentration. The Bijker transport formula is built up of two components, namely, a bed load transport component and a suspended load transport component. The 
bed load transport formula was adopted from the Kalinske-Frijlink formula (for bed load transport under river conditions). Bijker divided the Kalinske-Frijlink formula into a stirring parameter and a transport parameter. He introduced the influence of the waves via a modification of the bottom shear stress, $\tau_{c}$, in the stirring parameter into $\tau_{\mathrm{cw}}$. The remaining part, the transport parameter was adapted simply by neglecting the ripple factor, $\mu$. The bottom transport formula was written as;

$$
q_{b}=\frac{5 d_{50} V \sqrt{g}}{C} \exp \left[\frac{-0.27 \Delta d_{50} \rho g}{\mu \overline{\tau_{c w}}}\right]
$$

where $q_{b}$ is the bed load transport $\left(\mathrm{m}^{3} / \mathrm{sm}\right), d_{50}$ is the particle diameter, $V$ is the mean current velocity, $C$ is Chezy coefficient $\left(=18 \log \left(12 \mathrm{~h} / \mathrm{k}_{\mathrm{s}}\right)\right), \mathrm{k}_{\mathrm{s}}$ is the bottom roughness, $\mathrm{g}$ is the gravitational acceleration, $\Delta$ is the relative apparent density of bed material $\left(=\left(\rho_{\mathrm{s}}-\rho\right) / \rho\right), \rho_{\mathrm{s}}$ is the mass density of bed material, $\rho$ is the mass density of water, $\mu$ is the ripple factor $\left(=\left(\mathrm{C} / \mathrm{C}_{90}\right)^{1.5}\right), \mathrm{C}_{90}$ is Chezy coefficient based on $\mathrm{d}_{90}, \tau_{\mathrm{cw}}$ is the bed shear stress due to waves and current (time averaged).

$$
\overline{\tau_{c w}}=\frac{\rho g V^{2}}{C^{2}}\left[1+0.5\left(\xi \frac{\bar{u}_{o}}{V}\right)^{2}\right]
$$

where $\xi$ is Bijker parameter.

$$
\xi=C \sqrt{\frac{f_{w}}{2 g}}
$$

where $\mathrm{f}_{\mathrm{w}}$ is Jonsson's friction factor. Bijker assumed that the bottom transport occurred in a layer with a thickness equal to the bottom roughness, $\mathrm{k}_{\mathrm{s}}$, of the bed transport layer.

$$
C_{a}=\frac{q_{b}}{6.34 k_{s} u_{*}}
$$

Bijker coupled the adapted bed load transport formula to the suspended load transport formula of Einstein. After a lot of algebra the suspended sediment can be shown to be directly proportional to the bed load transport.

$$
q_{s}=1.83 Q q_{b}
$$

where

$$
Q=\left[I_{1} \ln \left(\frac{33 h}{k_{s}}\right)+I_{2}\right]
$$

$I_{1}$ and $I_{2}$ are known as the Einstein integrals;

$$
I_{1}=R \int_{A}^{1}\left\{\frac{1-\xi}{\xi}\right\}^{b} d \xi
$$




$$
I_{2}=R \int_{A}^{1}\left\{\frac{1-\xi}{\xi}\right\}^{b} \ln (\xi) d \xi
$$

where $\xi$ is the dimensionless height $(\mathrm{z} / \mathrm{h}), \mathrm{A}$ is the dimensionless roughness $\left(\mathrm{k}_{\mathrm{s}} / \mathrm{h}\right)$,

$$
\begin{gathered}
R=\frac{0.216 A^{(b-1)}}{(1-A)^{b}} \\
b=\frac{w}{\kappa u_{*}}
\end{gathered}
$$

$\mathrm{u} *$ is the shear stress velocity (influence of waves),

$$
\mathrm{u}^{*}: \mathrm{u}^{*}{ }_{\mathrm{CW}}=\sqrt{\frac{\tau_{c w}}{\rho}}
$$

values for the Einstein integral factor can be found in Table 1. When both the bed load and the suspended load are known, the total transport can be calculated. Additionally, since the suspended load transport is directly related to the bed load, a very simple relationship results may be found.

$$
\mathrm{q}_{\mathrm{t}}=\mathrm{q}_{\mathrm{b}}+\mathrm{q}_{\mathrm{s}}=\mathrm{q}_{\mathrm{b}}(1+1.83 \mathrm{Q})
$$

\section{CERC formula (USACE, 1984)}

The CERC formula was developed from prototype and model measurements long before much of the alongshore current theory had been developed. Indeed, the CERC formula was developed soon after World War II by the Beach Erosion Board, the predecessor of the U.S. Army Coastal Engineering Research Center. Observations in both prototype and model, made in the decade following World War II, indicated a correlation between the longshore transport rate and the longshore component of energy flux at the outer edge of the surf zone.

Assuming a dense sand with $\rho_{\mathrm{s}}=1800 \mathrm{~kg} / \mathrm{m}^{3}$ and porosity with $\mathrm{n}=0.32$, the formula is given:

$$
\begin{gathered}
\mathrm{q}_{\mathrm{t}}=2.9 \times 10^{6} \mathrm{H}_{\mathrm{sb}}^{5 / 2} \operatorname{sina}_{\mathrm{b}}\left(\mathrm{m}^{3} / \mathrm{yr}\right) \\
\mathrm{q}_{\mathrm{t}}=330 \mathrm{H}_{\mathrm{sb}}^{5 / 2} \operatorname{sina}_{\mathrm{b}}\left(\mathrm{m}^{3} / \mathrm{hr}\right)
\end{gathered}
$$

\section{Bailard and Inman formula (1981, 1984)}

Bailard and Inman (1981) derived a formula for both the suspended and bed load transport based on the energetics approach by Bagnold (1966). Bagnold assumed that the work done in transporting the sediment is a fixed portion of the total energy dissipated by the flow. The formula takes into account bed load and suspended load and flow associated with waves and current. Assuming that a weak longshore current prevails, neglecting effects of the slope term on the total transport rate for near-normal incident waves, the local time averaged longshore sediment transport rate is (Bailard, 1984). 


\begin{tabular}{|c|c|c|c|c|c|c|c|c|c|c|}
\hline \multirow[t]{2}{*}{$\mathrm{k}_{\mathrm{s}} / \mathrm{h}$} & \multicolumn{2}{|c|}{$\mathrm{b}=0.00$} & \multicolumn{2}{|c|}{$\mathrm{b}=0.20$} & \multicolumn{2}{|c|}{$\mathrm{b}=0.40$} & \multicolumn{2}{|c|}{$\mathrm{b}=0.60$} & \multicolumn{2}{|c|}{$\mathrm{b}=0.80$} \\
\hline & $\mathrm{Q}$ & $\mathrm{q}_{\mathrm{s} / \mathrm{q}_{\mathrm{b}}}$ & $\mathrm{Q}$ & $\mathrm{q}_{\mathrm{s} /} / \mathrm{q}_{\mathrm{b}}$ & Q & $\mathrm{q}_{\mathrm{s} / \mathrm{q}_{\mathrm{b}}}$ & $\mathrm{Q}$ & $\mathrm{q}_{\mathrm{s} / \mathrm{q}_{\mathrm{b}}}$ & Q & $\mathrm{q}_{\mathrm{s} / \mathrm{q}_{\mathrm{b}}}$ \\
\hline 0.00001 & 303000 & 554000 & 32800 & 60000 & 3880 & 7100 & 527 & 964 & 88 & 161 \\
\hline 0.00002 & 144000 & 263000 & 17900 & 32700 & 2430 & 4440 & 377 & 689 & 71.6 & 131 \\
\hline 0.00005 & 53600 & 98000 & 7980 & 14600 & 1300 & 2370 & 239 & 438 & 53.6 & 98 \\
\hline 0.0001 & 25300 & 46300 & 4320 & 7900 & 803 & 1470 & 169 & 310 & 42.7 & 78.2 \\
\hline 0.0002 & 11900 & 21800 & 2330 & 4260 & 496 & 907 & 119 & 218 & 33.9 & 62 \\
\hline 0.0005 & 4360 & 7980 & 1020 & 1870 & 260 & 475 & 74.3 & 136 & 24.6 & 45 \\
\hline 0.001 & 2030 & 3720 & 545 & 998 & 158 & 290 & 51.2 & 93.7 & 19.1 & 34.9 \\
\hline 0.002 & 940 & 1720 & 289 & 529 & 95.6 & 175 & 35.1 & 64.2 & 14.6 & 26.7 \\
\hline 0.005 & 336 & 615 & 123 & 226 & 48.5 & 88.7 & 20.8 & 38.1 & 10.0 & 18.3 \\
\hline 0.01 & 153 & 280 & 63.9 & 117 & 28.6 & 52.3 & 13.8 & 25.2 & 7.3 & 13.4 \\
\hline 0.02 & 68.9 & 126 & 32.8 & 60.0 & 16.5 & 30.2 & 8.9 & 16.3 & 5.2 & 9.5 \\
\hline 0.05 & 23.2 & 42.4 & 13.1 & 24.0 & 7.7 & 14.1 & 4.8 & 8.7 & 3.1 & 5.7 \\
\hline 0.1 & 9.8 & 18.0 & 6.3 & 11.5 & 4.1 & 7.5 & 2.8 & 5.1 & 2.0 & 3.6 \\
\hline 0.2 & 3.9 & 7.1 & 2.8 & 5.1 & 2.0 & 3.7 & 1.5 & 2.8 & 1.2 & 2.1 \\
\hline 0.5 & 0.8 & 1.5 & 0.7 & 1.3 & 0.6 & 1.1 & 0.5 & 0.9 & 0.4 & 0.7 \\
\hline 1 & 0 & 0 & 0 & 0 & 0 & 0 & 0 & 0 & 0 & 0 \\
\hline \multirow[t]{2}{*}{$\mathrm{k}_{\mathrm{s}} / \mathrm{h}$} & \multicolumn{2}{|c|}{$\mathrm{b}=1.00$} & \multicolumn{2}{|c|}{$\mathrm{b}=1.50$} & \multicolumn{2}{|c|}{$\mathrm{b}=2.00$} & \multicolumn{2}{|c|}{$\mathrm{b}=3.00$} & \multicolumn{2}{|c|}{$\mathrm{b}=4.00$} \\
\hline & Q & $\mathrm{q}_{\mathrm{s} /} / \mathrm{q}_{\mathrm{b}}$ & Q & $\mathrm{q}_{\mathrm{s} /} / \mathrm{q}_{\mathrm{b}}$ & Q & $\mathrm{q}_{\mathrm{s} / \mathrm{q}_{\mathrm{b}}}$ & Q & $\mathrm{q}_{\mathrm{s} / \mathrm{q}_{\mathrm{b}}}$ & Q & $\mathrm{q}_{\mathrm{s} /} / \mathrm{q}_{\mathrm{b}}$ \\
\hline 0.00001 & 20.0 & 36.6 & 2.33 & 4.26 & 0.973 & 1.78 & 0.432 & 0.790 & 0.276 & 0.505 \\
\hline 0.00002 & 17.9 & 32.8 & 2.31 & 4.23 & 0.973 & 1.78 & 0.432 & 0.790 & 0.276 & 0.505 \\
\hline 0.00005 & 14.4 & 28.2 & 2.28 & 4.17 & 0.967 & 1.77 & 0.432 & 0.790 & 0.276 & 0.505 \\
\hline 0.0001 & 13.6 & 24.9 & 2.25 & 4.11 & 0.967 & 1.77 & 0.432 & 0.790 & 0.276 & 0.505 \\
\hline 0.0002 & 11.9 & 21.8 & 2.21 & 4.04 & 0.967 & 1.77 & 0.431 & 0.789 & 0.275 & 0.504 \\
\hline 0.0005 & 9.8 & 17.9 & 2.13 & 3.90 & 0.962 & 1.76 & 0.431 & 0.789 & 0.275 & 0.504 \\
\hline 0.001 & 8.4 & 15.3 & 2.05 & 3.76 & 0.951 & 1.74 & 0.430 & 0.787 & 0.275 & 0.504 \\
\hline 0.002 & 7.0 & 12.8 & 1.96 & 3.58 & 0.940 & 1.72 & 0.428 & 0.784 & 0.274 & 0.502 \\
\hline 0.005 & 5.4 & 9.8 & 1.78 & 3.26 & 0.907 & 1.66 & 0.424 & 0.776 & 0.273 & 0.499 \\
\hline 0.01 & 4.3 & 7.8 & 1.62 & 2.96 & 0.869 & 1.59 & 0.417 & 0.763 & 0.270 & 0.494 \\
\hline 0.02 & 3.3 & 6.0 & 1.42 & 2.59 & 0.809 & 1.48 & 0.404 & 0.740 & 0.264 & 0.483 \\
\hline 0.05 & 2.2 & 4.0 & 1.10 & 2.02 & 0.694 & 1.27 & 0.374 & 0.684 & 0.249 & 0.456 \\
\hline 0.1 & 1.5 & 2.7 & 0.84 & 1.53 & 0.568 & 1.04 & 0.339 & 0.620 & 0.236 & 0.432 \\
\hline 0.2 & 0.9 & 1.6 & 0.55 & 1.01 & 0.414 & 0.76 & 0.317 & 0.580 & & \\
\hline 0.5 & 0.3 & 0.6 & 0.17 & 0.32 & & & & & & \\
\hline 1 & 0 & 0 & 0 & 0 & & & & & & \\
\hline
\end{tabular}

Table 1. Values of Einstein integral factor $Q$ and values of the ratio suspended load to bed load.

$$
q=0.5 \rho f_{w} u_{0}^{3} \frac{e_{b}}{\left(\rho_{s}-\rho\right) g \tan \gamma}\left(\frac{\delta_{v}}{2}+\delta_{v}^{3}\right)+0.5 \rho f_{w} u_{0}^{4} \frac{e_{s}}{\left(\rho_{s}-\rho\right) g w_{s}}\left(\delta_{v} u_{3}^{*}\right)
$$

where $e_{b}$ and $e_{s}$ are the efficiency factors and typically used values in calculations are 0.1, 0.02 respectively, although work has indicated that these are related to the bed shear stress and the particle diameter they are assumed to be constant, $\tan \gamma(=0.63)$ is a dynamic friction factor. In Equation (18) the first term is bed load and the second term is the suspended load component. 


$$
\begin{gathered}
\delta_{v}=\frac{V}{u_{0}} \\
u_{3}^{*}=\frac{\left\langle\left|u_{t}^{\prime}\right|^{3}\right\rangle}{u_{0}}
\end{gathered}
$$

in which $U_{t}^{\prime}$ is the instantaneous velocity vector near the bed (wave and current)

Van Rijn formula $(1984,1993)$

Van Rijn (1984) presented comprehensive formulas for calculating the bed load and suspended load, and only a short description of the method is given in the following. For the bed load he adapted the approach of Bagnold assuming that sediment particles jumping under the influence of hydrodynamic fluid forces and gravity forces dominate the motion of the bed load particles.

$$
q_{b}=0.25 \gamma \rho_{s} d_{50} D_{\star}^{-0.3} \sqrt{\frac{\tau_{b, w c}^{\prime}}{\rho}}\left[\frac{\tau_{b, w c}^{\prime}-\tau_{b, c r}}{\tau_{b, c r}}\right]^{1.5}
$$

in which $D^{*}$ is the dimensionless grain diameter, $\tau_{b, w c}^{\prime}$ is the effective bed shear stress for waves and current combined / calculated according to Van Rijn's own method (not discussed here).

$$
\begin{gathered}
D_{*}=d_{50}\left[\frac{(s-1) g}{v^{2}}\right]^{1 / 3} \\
\gamma=1-\sqrt{\frac{H_{s}}{h}}
\end{gathered}
$$

in which $\mathrm{H}_{\mathrm{s}}$ is the significant wave height.

The depth integrated suspended load transport in the presence of current and waves is defined as the integration of the product of velocity and concentration from the edge of the bed-load layer to the water surface yields

$$
q_{s}=c_{a} V h \frac{1}{h} \int_{a}^{h} \frac{v}{V} \frac{c}{c_{a}} d z=c_{a} V h F
$$

where $\mathrm{c}$ is the concentration distribution, $\mathrm{V}$ is the mean longshore current, and

$$
\begin{gathered}
F=\frac{V_{*}}{\kappa V}\left(\frac{a}{h-a}\right)^{Z}\left(\int_{a / h}^{0.5}\left(\frac{h-z}{z}\right)^{Z^{\prime}} \ln \left(z / z_{0}\right) d(z / h)+\int_{0.5}^{1} e^{-4 Z^{\prime}(z / h-0.5)} \ln \left(z / z_{0}\right) d(z / h)\right) \\
\mathcal{C}_{a}=0.015 \frac{d_{50}}{a} \frac{T^{1.5}}{D_{*}^{0.3}} \\
Z^{\prime}=Z+\Psi \\
Z=\frac{w}{\beta \kappa V_{*}}
\end{gathered}
$$




$$
\begin{gathered}
\Psi=2.5\left(\frac{w}{V_{*}}\right)^{0.8}\left(\frac{c_{a}}{c_{0}}\right)^{0.4} \\
\beta=1+2\left(\frac{w}{V}\right)^{2}
\end{gathered}
$$

in which $\mathrm{Z}$ is the suspension parameter reflecting the ratio of the downward gravity forces and upward fluid forces acting on a suspended sediment particle in a current, $\psi$ is an overall correction factor representing damping and reduction in particle fall speed due to turbulence and $\beta$ is a coefficient quantifying the influence of the centrifugal forces on suspended particles.

Van Rijn (1984) calculated the concentration distribution c in three separate layers, namely;

1. from the reference level a to the end of a near-bed mixing layer (of thickness $\delta_{\mathrm{s}}$ )

2. from the top of the $\delta_{\mathrm{s}}$-layer to half the water depth $(\mathrm{h} / 2)$

3. from $(\mathrm{h} / 2)$ to $\mathrm{h}$

Different exponential or power functions are employed in these regions with empirical expressions depending on the mixing characteristics in each layer.

Kamphuis formula (1991)

Kamphuis (1991) proposed a formula for the longshore sediment transport (LST) rate based on three-dimensional, mobile-bed hydraulic beach model experiments performed with both regular and irregular waves. After a detailed dimensional analysis he expressed the longshore sediment transport rate as a function of wave steepness, beach slope, relative grain size and wave angle. The scale effect for the sediment transport rate was obtained very small. The transport formula is expressed as;

$$
Q=2.27 H_{s b}^{2} T_{p}^{1.5} m_{b}^{0.75} d_{50}^{-0.25} \sin ^{0.6}\left(2 \alpha_{b}\right)(\mathrm{kg} / \mathrm{s})
$$

where $\mathrm{H}_{\mathrm{sb}}$ is the significant wave height at the breaking point, $\mathrm{T}_{\mathrm{p}}$ is the peak wave period, $m_{b}$ is the beach slope near the breaking point, $d_{50}$ is the median grain size, $\alpha$ is the breaking wave angle. Equation (31) can be converted to

$$
Q=6.4 .10^{4} H_{s b}^{2} T_{p}^{1.5} m_{b}^{0.75} d_{50}^{-0.25} \sin ^{0.6}\left(2 \alpha_{b}\right)\left(\mathrm{m}^{3} / \mathrm{yr}\right)
$$

or

$$
Q=7.3 H_{s b}^{2} T_{p}^{1.5} m_{b}^{0.75} d_{50}^{-0.25} \sin ^{0.6}\left(2 \alpha_{b}\right)\left(\mathrm{m}^{3} / \mathrm{hr}\right)
$$

The formula is more sensitive to wave period than the earlier expressions. Kamphuis (2010) expressed that these expressions over-predicts transport for gravel beaches because they do not include a critical shear stress (they assume that particles move even for small wave conditions, which is true for sand but not for gravel).

Watanabe et al. formula $(1986,1992)$

Watanabe et al. (1986) proposed a power-model type formula for local sediment transport rate under combined action of waves and currents as the summation of the transport rate due to mean currents and that due to the direct action of waves.

$$
q(x)=\left(1-\varepsilon_{v}\right) s A_{c}\left[\frac{\left(\tau_{b, w c}-\tau_{b, c r}\right) V(x)}{\rho g}\right]
$$


in which $\varepsilon_{\mathrm{v}}$ is the porosity, $\mathrm{s}\left(=\rho_{\mathrm{s}} / \rho-1\right)$ is the immersed specific density of the sediment, $\mathrm{A}_{\mathrm{c}}$ is a dimensionless coefficient, $\tau_{\mathrm{b}, \mathrm{wc}}$ is the maximum value of the periodical bottom friction in a coexistent wave-current field, $\tau_{\mathrm{b}, \mathrm{cr}}$ is the critical shear stress for the onset of general sand movement and $\mathrm{V}$ is the longshore current velocity. A value of 2.0 was adopted for the coefficient $\mathrm{A}_{\mathrm{c}}$. Total immersed-weight rate of the alongshore transport can be computed by the cross-shore integration of the Equation (34). The total volumetric transport rate $Q$ is calculated by the below equation:

$$
Q=\frac{\int_{x_{0}}^{\infty} q(x) d}{\left(1-\varepsilon_{v}\right)\left(\rho_{s}-\rho\right) g}
$$

Watanabe (1992) studied the cross-shore distribution of the longshore transport rate. He expressed that the transport rate $\mathrm{q}(\mathrm{x})$ becomes maximum between the breaking point and the location of the maximum longshore current velocity.

\section{Damgaard and Soulsby formula (1997)}

Damgaard and Soulsby (1997) derived a physics-based formula for bed load alongshore sediment transport. It is intended primarily for use on shingle beaches, although it is also applicable to the bed load component on sandy beaches. The general principles are that the mean bed shear stress are calculated from the gradient of the radiation stress in the surf zone and the oscillatory bed shear stresses recalculated from the wave orbital velocities using a wave friction factor corresponding to the maximum of the values for rough turbulent flow and for sheet flow using an expression derived by Wilson (1989). The resulting formula is:

$\mathrm{q}_{\mathrm{t}}=$ maximum of $\mathrm{q}_{\mathrm{t} 1}$ and $\mathrm{q}_{\mathrm{t} 2}$

$$
\begin{aligned}
& q_{t 1}=\frac{0.19(g \tan \beta)^{1 / 2}\left(\sin 2 \alpha_{b}\right)^{3 / 2} H_{b}^{5 / 2}\left(1-\hat{\theta}_{c r}\right)}{12(s-1)} \text { for } \quad \hat{\theta}_{c r}<1 \\
& =0 \quad \text { for } \hat{\theta}_{c r} \geq 1 \\
& q_{t 2}=\frac{0.24 f\left(\alpha_{b}\right) g^{3 / 8} d_{50}^{1 / 4} H_{b}^{19 / 8}}{12(s-1) T^{1 / 4}} \quad \text { for } \quad \theta_{w r} \geq \theta_{w s f} \\
& q_{t 2}=\frac{0.046 f\left(\alpha_{b}\right) g^{2 / 5} H_{b}^{13 / 5}}{12(s-1)^{6 / 5}(\pi T)^{1 / 5}} \quad \text { for } \quad \theta_{w r}<\theta_{w s f}
\end{aligned}
$$

Subject to $\mathrm{q}_{\mathrm{t} 2}=0$ for $\theta_{\max } \leq \hat{\theta}_{c r}$

where

$$
\begin{gathered}
\hat{\theta}_{c r}=\frac{16.7 \theta_{c r}(s-1) d_{50}}{H_{b}\left(\sin 2 \alpha_{b}\right)(\tan \beta)} \\
f\left(\alpha_{b}\right)=\left(0.95-0.19 \cos 2 \alpha_{b}\right)\left(\sin 2 \alpha_{b}\right) \\
\theta_{w r}=\frac{0.15 H_{b}^{3 / 4}}{(s-1) g^{1 / 4}\left(T d_{50}\right)^{1 / 2}}
\end{gathered}
$$




$$
\theta_{w s f}=\frac{0.0040 H_{b}^{6 / 5}}{(s-1)^{7 / 5} g^{1 / 5} T^{2 / 5} d_{50}}
$$

$\theta_{\mathrm{w}}=$ maximum of $\theta_{\mathrm{wr}}$ and $\theta_{\mathrm{wsf}}$

$$
\begin{gathered}
\theta_{m}=\frac{0.1 H_{b}\left(\sin 2 \alpha_{b}\right)(\tan \beta)}{(s-1) d_{50}} \\
\theta_{\max }=\left[\left(\theta_{m}+\theta_{w} \sin \alpha_{b}\right)^{2}+\left(\theta_{w} \cos \alpha_{b}\right)^{2}\right]^{1 / 2} \\
\hat{\theta}_{c r}=\frac{0.30}{1+1.2 D_{*}}+0.055\left[1-\exp \left(-0.02 D_{*}\right)\right] \text { threshold Shields parameter } \\
D_{*}=\left[\frac{g(s-1)}{v^{2}}\right]^{1 / 3} d
\end{gathered}
$$

where $\mathrm{H}_{\mathrm{b}}$ is the wave height at breaker line, $\mathrm{T}$ is the wave period, $\mathrm{d}_{50}$ is the median grain diameter, $\tan \beta$ is the beach slope.

Bayram et al. formula (2007)

Bayram et al. (2007) presented a new formula for calculating the longshore sediment transport (LST) rate. This formula is derived based on an average concentration and alongshore current velocity for the surf zone, where the current may originate from breaking waves, wind, or tides. The new formula was validated with an extensive data set covering a wide range of conditions. They assumed that the presence of breaking waves cause to mobilize sediment, whereas any type of current (e.g., from breaking waves, wind and tide) can transport the sediment. This new formula consider that the flux of wave energy towards shore is $\mathrm{F}(=\mathrm{EC} \mathrm{g})$ and a certain portion $\varepsilon$ of this energy is used for the work $\mathrm{W}$, that is, $\mathrm{W}=\varepsilon \mathrm{F}$. This formula is given as follows;

$$
\mathrm{Q}_{1 \mathrm{st}}=\frac{\varepsilon}{\left(\rho_{\mathrm{s}}-\rho\right)(1-\mathrm{a}) \mathrm{gw}_{\mathrm{s}}} \mathrm{F} \overline{\mathrm{V}}
$$

where $\bar{V}$ is the mean alongshore current velocity over the surf zone and a is the porosity, $\varepsilon$ is the transport coefficient. The transport coefficient depends on wave and sediment conditions. They also indicated that the wave-energy flux is given by,

$$
\mathrm{F}_{\mathrm{b}}=\mathrm{E}_{\mathrm{b}} \mathrm{C}_{\mathrm{gb}} \cos \theta_{\mathrm{b}}
$$

where $E_{b}$ is the wave energy per unit crest width, $C_{g b}$ is the group velocity and index $b$ denotes incipient breaking. Neglecting energy dissipation seaward of the surf zone (ie., bottom friction), the wave-energy flux can be estimated at any depth since $F=F_{b}$. The transport coefficient is given by,

$$
\varepsilon=\left(9.0+4.0 \frac{\mathrm{H}_{\mathrm{s}, \mathrm{b}}}{\mathrm{w}_{\mathrm{s}} \mathrm{T}_{\mathrm{p}}}\right) 10^{-5}
$$

where $H_{s, b}$ is the significant wave height at breaking, $T_{p}$ is the peak wave period, $w_{s}$ is the particle settling velocity. 


\section{Modelling of shoreline change}

\subsection{Introduction}

Determination of the shoreline change and coastal morphology accurately in coastal zones is a very important issue for the "Integrated Coastal Zone Management". For the assessment of the coastal morphology and shoreline change, the most important environmental parameters as wind, wave, current, water level, sediment transport phenomena and its supply should be well known. However, these parameters can not be detected accurately and properly due to the complicated behaviour of the nature. Prediction of the beach evolution for beach stabilization or shore protection is one of the main responsibilities in the field of coastal engineering. Despite of the difficulty of the problem, accurate estimations must be performed for the design and maintenance of the shore protection projects.

In the planning of projects located in the nearshore zone, prediction of beach evolution with numerical models has proven to be a powerful technique to assist in the selection of the most appropriate design. Models provide a framework for developing problem formulation and solution statements, for organizing the collection and analysis of data, and, importantly, for efficiently evaluating alternative designs and optimizing the selected design (Hanson and Kraus, 1991).

Various modelling approaches ranging from simple one-dimensional to sophisticate threedimensional models for prediction and assessment of the evolution of coastal morphology have been developed over the last decades. Recently, these models have become useful in representing the governing physical processes in cross-shore and alongshore dimensions.

In numerical modelling of coastal processes there is a tendency to develop that attempt to simulate the physical processes in fine detail. This results in very specialized computationally extensive models, which are very difficult to handle. Given the complexity of the coastal processes, which can not be represented by deterministic formula and the high uncertainty in wave and sediment transport data (Kamphuis, 1999), numerous runs are required for sensitivity analysis and model calibration and verification which prohibit the practical application of such sophisticated model (Dabees, 2000).

Numerical models of beach evolution expand from simple one-dimensional models to complicated three dimensional models. These models can be classified as:

- $\quad$ Beach profile change models:

Descriptive models

Equilibrium profile models

Process based models

- Analytical shoreline change models

- Numerical shoreline change models

- Numerical three dimensional beach change models:

Deterministic three dimensional models

Schematic three dimensional models (N-line)

\subsection{Numerical shoreline change models}

Analytical and numerical models are developed based on the equations of sediment continuity (48) and longshore transport rate (49) which are the governing processes in the long-term response of shoreline evolution.

$$
\frac{d y}{d t}=-\frac{1}{d_{p}}\left\{\frac{d Q}{d x}-q\right\}
$$


where $\mathrm{y}$ is the shoreline position, $\mathrm{x}$ is the longshore coordinate, $\mathrm{t}$ is the time, $\mathrm{Q}$ is the volume rate of longshore sediment transport, $\mathrm{q}$ is the rate of cross-shore sediment transport or sediment sources along the coast, $d_{p}$ is the profile depth which equals to the closure depth $\left(d_{c}\right)$ plus the beach berm height $\left(d_{b}\right)$.

\section{Analytical solutions}

The first one-line theory used for the determination of the shoreline change was introduced by Pelnard-Considere (1956). The analytical one-line theory was used for planform shoreline evolution by employing equilibrium profile. By assuming constant wave direction and a small incident wave angle, the longshore transport rate can be calculated with Equation (49).

$$
\mathrm{Q}=f\left(\mathrm{H}_{\mathrm{b}}, \alpha_{b}, \tan \beta, \mathrm{d}_{50}\right)=\mathrm{Q}_{0} \sin 2 \alpha_{e}=\mathrm{Q}_{0} \sin 2\left(\alpha_{b}-\frac{d y}{d x}\right)
$$

where, $\mathrm{Q}_{0}$ is the amplitude of longshore transport rate, $\mathrm{Q}$ is the volume rate of longshore sediment transport, $\alpha_{b}$ is the wave breaking angle with respect to the X-axis and $\alpha_{e}$ is the effective breaking angle.

The effective breaking angle is defined as:

$$
\alpha_{e}=\alpha_{b}-\alpha_{s}
$$

$\alpha_{s}=\tan ^{-1}(d y / d x)$ is the angle the shoreline makes with the X-axis. Following the assumption that $\alpha_{s}$ is small such that $\alpha_{s}=(d y / d x)$. Equation (50) becomes:

$$
\alpha_{e}=\alpha_{b}-\frac{d y}{d x}
$$

Assuming small incident angle, Equation (49) is given by,

$$
\mathrm{Q}=2 \mathrm{Q}_{0}\left(\alpha_{b}-\frac{d y}{d x}\right)
$$

Differentiating Equation (52) to determine $\partial Q / \partial x$ and substituting in Equation (48) assuming that $\mathrm{q}=0$, the governing equation is simplified in the form of diffusion equation for shoreline evolution below:

where;

$$
\frac{d y}{d t}-\underline{D} \frac{d^{2} y}{d x^{2}}=0
$$

$$
\underline{D}=\frac{2 Q_{0}}{d_{p}}=\frac{Q}{\alpha_{b} d_{p}}
$$

Many solutions to various initial and boundary conditions for Equation (53) have been presented (Carlslaw and Jaeger, 1959; Crank and Jaeger, 1975). Grijm (1961) derived the analytical solution for the shoreline evolution of horizontal bed response to the sediment discharges from a river. Le Mehaute and Soldate (1977) developed a mathematical model which incorporates different effects of variations of sea level, wave refraction, diffraction, rip currents, coastal structures and beach nourishment for long-term shoreline evolution. Larson et al. (1987) surveyed 25 analytical models for simulating the evolution of a sandy beach. A general solution using Laplace transformation techniques for beach evolution with 
and without structures was developed. Walton (1994) derived three one-line models in which two of them are linearised shoreline change models and the other one is non-linear model using different approaches. Dean (2002) has extended his previous research (Dean, 1984) on analytical solutions of shoreline change applicable to beach nourishment projects. Several solutions to the diffusion equation for shoreline evolution are presented for various geometries, different initial and boundary conditions.

The analytical models supply simple and economic solutions for the shoreline behaviour for various coastal problems. However analytical models with several constraints limit the practical applications in the field. In Table 2 assumptions and limitations of the analytical solutions are given.

\begin{tabular}{|c|l|l|}
\hline \multicolumn{1}{|c|}{ Assumption } & \multicolumn{1}{c|}{ Limitation } \\
\hline $\mathbf{1}$ & Constant profile shape & $\begin{array}{l}\text { Unable to describe changes in profile shape in } \\
\text { time and space. }\end{array}$ \\
\hline $\mathbf{2}$ & $\begin{array}{l}\text { No cross-shore transport } \\
\mathrm{q}=0\end{array}$ & $\begin{array}{l}\text { Small breaking angle } \\
\left(\text { sin } 2 \alpha_{b}=2 \alpha_{b}\right)\end{array}$ \\
\hline $\mathbf{4}$ & $\begin{array}{l}\text { Small shoreline change angle } \\
\text { losses or seasonal variations. }\end{array}$ & Valid only for small breaking angles. \\
\hline $\mathbf{5}$ & $\begin{array}{l}\text { Constant wave condition in } \\
\text { space }\end{array}$ & $\begin{array}{l}\text { Valid only for straight shorelines. } \\
\text { Provides inaccurate results near structures. }\end{array}$ \\
\hline $\mathbf{6}$ & $\begin{array}{l}\text { Constant wave condition in } \\
\text { time }\end{array}$ & $\begin{array}{l}\text { Enable to account for changes in wave heights } \\
\text { Exclusion of wave refraction provides } \\
\text { inaccurate predictions of shoreline change for } \\
\text { curved shorelines. }\end{array}$ \\
\hline $\mathbf{7}$ & $\begin{array}{l}\text { Valid only for one representative wave } \\
\text { condition. } \\
\text { Unable to provide time dependent simulations } \\
\text { using actual wave climate. }\end{array}$ \\
\hline
\end{tabular}

Table 2. Assumptions and limitations of the analytical solution of the one-line theory (Dabees, 2000)

\section{Numerical solutions}

In the numerical models of shoreline change, the governing equation (48) is converted to finite difference forms (55)-(57) using a typical staggered grid representation. In Figure 1, shoreline position (y), cross-shore supply (q) and longshore sediment transport rate (Q) are defined for the longshore position $(\mathrm{x})$. $\mathrm{i}$ and prime (') denote the cell number and variables in the next time step, respectively.

$$
\frac{y_{i}^{\prime}-y_{i}}{\Delta t}=\lambda\left(\frac{\partial y}{\partial t}\right)_{i}+(1-\lambda)\left(\frac{\partial y}{\partial t}\right)_{i}^{\prime}
$$




$$
\begin{aligned}
& \left(\frac{\partial y}{\partial t}\right)_{i}=-\frac{1}{d_{p}}\left(\frac{Q_{i+1}-Q_{i}}{\partial y}-q_{i}\right) \\
& \left(\frac{\partial y}{\partial t}\right)_{i}^{\prime}=-\frac{1}{d_{p}}\left(\frac{Q_{i+1}^{\prime}-Q_{i}^{\prime}}{\partial y}-q_{i}^{\prime}\right)
\end{aligned}
$$

where $\Delta t$ is the time step and $\lambda(0 \leq \lambda \leq 1)$ is a parameter for selected numerical schemes. For the shoreline change models, both of the finite difference equations (explicit or implicit) can be used depending on the selected $\lambda$. For explicit schemes, the shoreline can be directly computed using previous information (the solution corresponding to $\lambda=1$ ). Implicit schemes are more complicated to program than explicit schemes. The further reading for the implicit and explicit finite difference schemes for shoreline change modelling can be found in Kamphuis (2010).

A considerable number of numerical one-line models have been explained in the literature with different formulations of initial and boundary conditions for shoreline evolutions in response to coastal structures and beach nourishments. There are a lot of numerical models apart from "in-house" numerical models that are all based on one-line theory and all widely known numerical modelling systems used in coastal engineering practice (for example GENESIS (Hanson and Kraus, 1991); UNIBEST (Delft, 1993); SAND94 (Szmytkiewicz et al., 2000); LITPACK (DHI, 2008)).

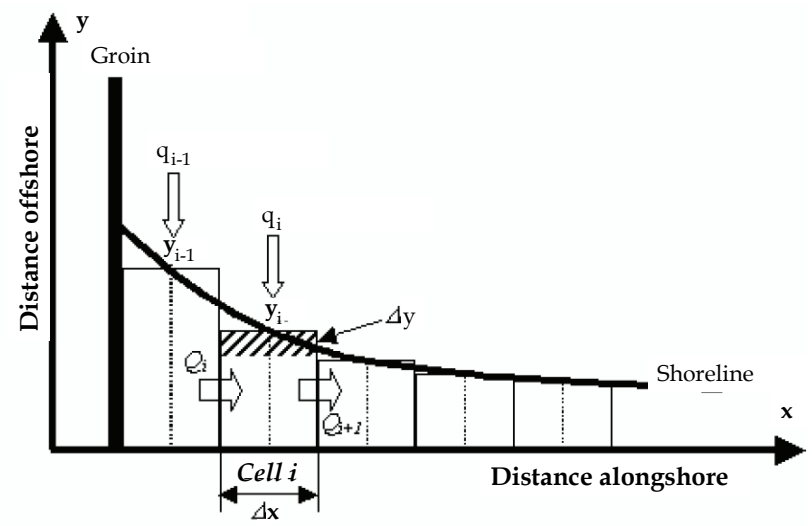

Fig. 1. Sketch of shoreline position and transport rates in finite difference form (Horikowa, 1988)

\section{Case study}

The site of the field study is Karaburun coastal village located near the south west coast of the Black Sea at $41^{\circ} 21^{\prime} 05^{\prime \prime} \mathrm{N}$ and $28^{\circ} 41^{\prime} 01^{\prime \prime} \mathrm{E}$, which is Northwest of Istanbul (Figure 2). It has a WNW-ESE general orientation and an extension of approximately $4 \mathrm{~km}$. The fishery harbor of the village is at the western end of the $4 \mathrm{~km}$ sandy beach. The harbor operations are effected by the sedimentation problem because of considerable rate of westward sediment transport towards the harbor entrance, thus the water depth shallows and the navigation to and from the harbor is prevented (Photo 1). 


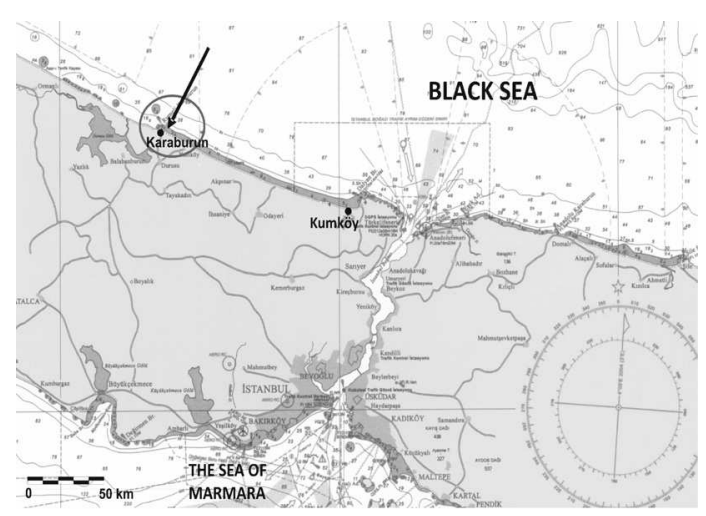

Fig. 2. Location of Karaburun coastal village

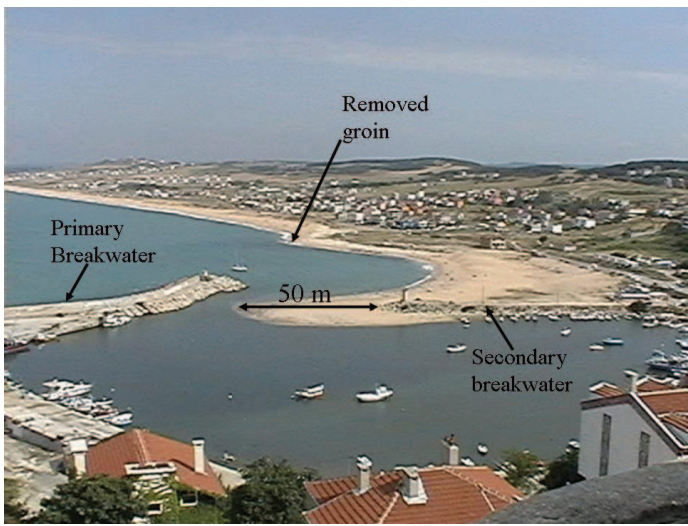

Photo 1. Karaburun Fishery Harbor and the nearby beach at east of Harbor (looking towards south east direction) (Ari et al., 2007)

\subsection{Prediction of longshore sediment transport rate}

In order to determine the LST rates in this region; the long-term observations of shoreline changes, sea bottom topography, sediment properties, wind, wave and current measurement campaigns were performed. The LST rates are obtained from three different methods which are:

- CERC (USACE,1984) formula

- Kamphuis (1991) formula

- $\quad$ Numerical model (LITPACK (DHI, 2008))

CERC (USACE,1984) and Kamphuis (1991) formulas are explained in the first part of this chapter in detail. The LST rates obtained from these models are given in Table 2.

The numerical model used in the current work is LITPACK package which is an integrated modelling system for LITtoral Processes and Coastline Kinetics developed by Danish Hydraulic Institute. LITPACK is used for modelling of non-cohesive sediment transport in waves and currents, littoral drift, coastline evolution and profile development. It is an integration and enhancement of deterministic numerical models: STP, LITDRIFT, LITLINE, 
LITREN, LITPROF. For the current study, the LITPACK package (ver. 2008, the newest available for this study) licensed at the Hydraulic and Coastal Engineering Laboratory at Yildiz Technical University has been used. LITPACK uses a sophisticated approach involving wave radiation stress computations for the evaluation of longshore sediment flux. A detailed description of the approach can be found in Fredsøe and Deigaard (1992).

LITDRIFT module was used for the estimation of LST rates of the study field. The module includes important sediment transport mechanisms such as non-linear wave motion, turbulent bottom boundary layer, wave breaking and sediment grading. It is an essentially combination of a 1D wave model, a 1D hydrodynamic model and an intra-wave sediment transport model (STP). The model shoals, refracts and breaks the input wave from the toe of the profile to the shoreline.

The input data for the LITDRIFT module is the wave data from the wave modelling results calibrated with the locally measured wave data, wind data, bottom profiles at different coordinates, initial coastline and sediment characteristics. In reference to the site measurements the median grain diameter $\left(d_{50}\right)$ and the sediment spreading $\left(\sigma_{g}=\sqrt{d_{84} / d_{16}}\right)$ were chosen as $1.53 \mathrm{~mm}$ and 1.36, respectively.

According to the calculations for the research area, the gross and the net longshore sediment transport rates were obtained as shown in Table 2.

\begin{tabular}{ccc}
\hline & $Q_{\text {net }}\left(\mathrm{m}^{3} /\right.$ year $)$ & Q gross $\left(\mathrm{m}^{3} /\right.$ year $)$ \\
\hline CERC (USACE, 1984) & 443292 & 772350 \\
Kamphuis (1991) & 76448 & 186510 \\
Numerical Model (LITDRIFT) & 85210 & 152600 \\
\hline
\end{tabular}

Table 2. The net and gross longshore sediment transport rates predicted by different methods

LST rates are estimated both by modelling and field measurements. However, both of these methods have major limitations and there is no independent argument of the accuracy of either. The limitations and/or the defects of the sediment transport models are criticised by several researchers. For this reason, LST rates predicted by these methods differ from each other by various reasons as shown in Table 2.

CERC formula used to be the most frequently applied expression which yields to the new models that include more coastal parameters nowadays. It is recommended to use CERC formula in storm conditions where the wave heights exceed $4 \mathrm{~m}$ (Wang et al, 1998). However, in Karaburun coastal region according to the wave climate studies, the average wave height is $0.9 \mathrm{~m}$. Therefore, CERC equation overestimates LST rates obtained from Kamphuis (1991) and numerical model (LITDRIFT) by factors of 5.8 and 5.2, respectively for the net LST and by factors of 4.1 and 5.1, respectively for the gross LST.

It is recommended to use Kamphuis (1991) formula in low-wave energy conditions with breaker heights of less then $1 \mathrm{~m}$ (Wang et al., 1998). The recommended value corresponds to the study area's wave condition. The percentage differences with respect to CERC equation and numerical model (LITDRIFT) are $141.2 \%$ and $10.8 \%$, respectively for the net LST, $122.2 \%$ and $20.0 \%$, respectively for the gross LST.

The other method to predict the LST rate in the region is the numerical model (LITDRIFT). The percentage differences for the net LST with respect to CERC equation and Kamphuis (1991) formula are $135.5 \%$ and $10.8 \%$, respectively, $134.0 \%$ and $20.0 \%$, respectively for the gross LST. 


\subsection{Determination of shoreline change}

The direction of the longshore sediment transport was determined as towards Northwest (towards the fishery harbor) from the field studies and measurements. Because of this transport, there becomes a considerable sediment deposition in and nearby the Karaburun fishery harbor.

Determination of the shoreline change evolution was performed with two methods. One of them is "in-house" numerical model and the other one is widely known numerical modelling system called LITLINE which is a module of LITPACK software package. Both of the models are based on one-line theory for shoreline change modelling.

In the first model (Ari et al., 2007), the shoreline change was investigated between the years of 1996 and 2005. Multitemporal and georeferenced IKONOS images (in 2003 and in 2005, multispectral) and IRS1C/D images (in 1996 and in 2000) were used in this study. The Karaburun shoreline was digitized manually by using ERDAS software for each image. The shorelines were superimposed and the changes of them had been measured in $50 \mathrm{~m}$ interval.

Karaburun shoreline was modeled by using 71 grid-cells, each $50 \mathrm{~m}$ long for the distance of $3.55 \mathrm{~km}$. In the first model the shoreline was idealized as shown in Figure 3. Both updrift and downdrift boundaries were assumed as complete barriers. The fishery harbor is located at downdrift boundary and there is a headland at the updrift boundary.

The first simulations were carried out for the period from 1996 to 1997 using a 3-hour time step. The initial shoreline obtained from the image in 1996 was used in the model. In order to calculate shoreline position in 2000, each model run considered the previous computed shoreline change for one year as an initial shore.

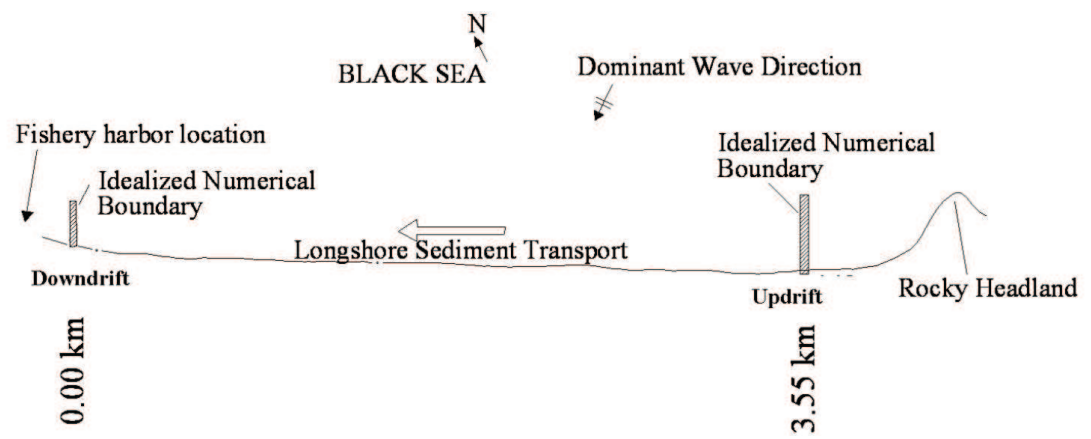

Fig. 3. Idealized numerical shoreline (Ari et al., 2007)

The results of the simulation of the present condition are seen in Figure 4. As shown from the figure, erosion occurs at the updrift side and deposition occurs at the downdrift side. The computed shoreline change was found nearly close the shoreline in 2000 from the image. However, sand fill was made in the eroded area in 2000. So erosion was reduced after 2000. The IKONOS images in 2003 and 2005 were agreed the result because shoreline change reached almost its equilibrium stage (Ari et al., 2007).

The second model used in the study is LITLINE module of LITPACK software package. LITLINE is the module that computes the changes of a shoreline over a period of time using spatially and temporally varying longshore transport. LITLINE calculates the coastline position based on input of the wave climate as a time series. The model is, with minor modifications, based on an one-line theory, in which the cross-shore profile is assumed to remain unchanged during erosion/accretion. 
Karaburun shoreline was modeled by using 463 grid-cells, each $10 \mathrm{~m}$ long for the distance of $4.63 \mathrm{~km}$ (1.08 km longer than the first model). In the second model no idealized boundaries were used. The headland was used in the LITLINE module as it is. The simulation was carried out for the period from 2004 to 2005 using a 1-hour time step.

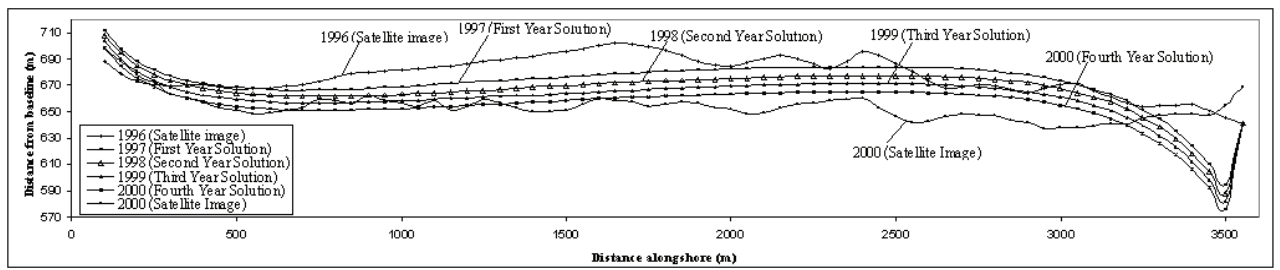

(a) Numerical solution (for four years) versus images in 1996 and 2000

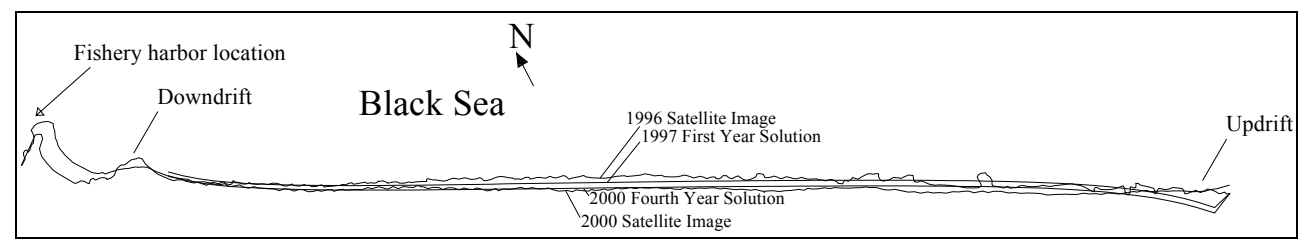

(b) Numerical solution in 1997 and 2000 versus images in 1996 and 2000

Fig. 4. Karaburun shoreline changes (Ari et al., 2007)

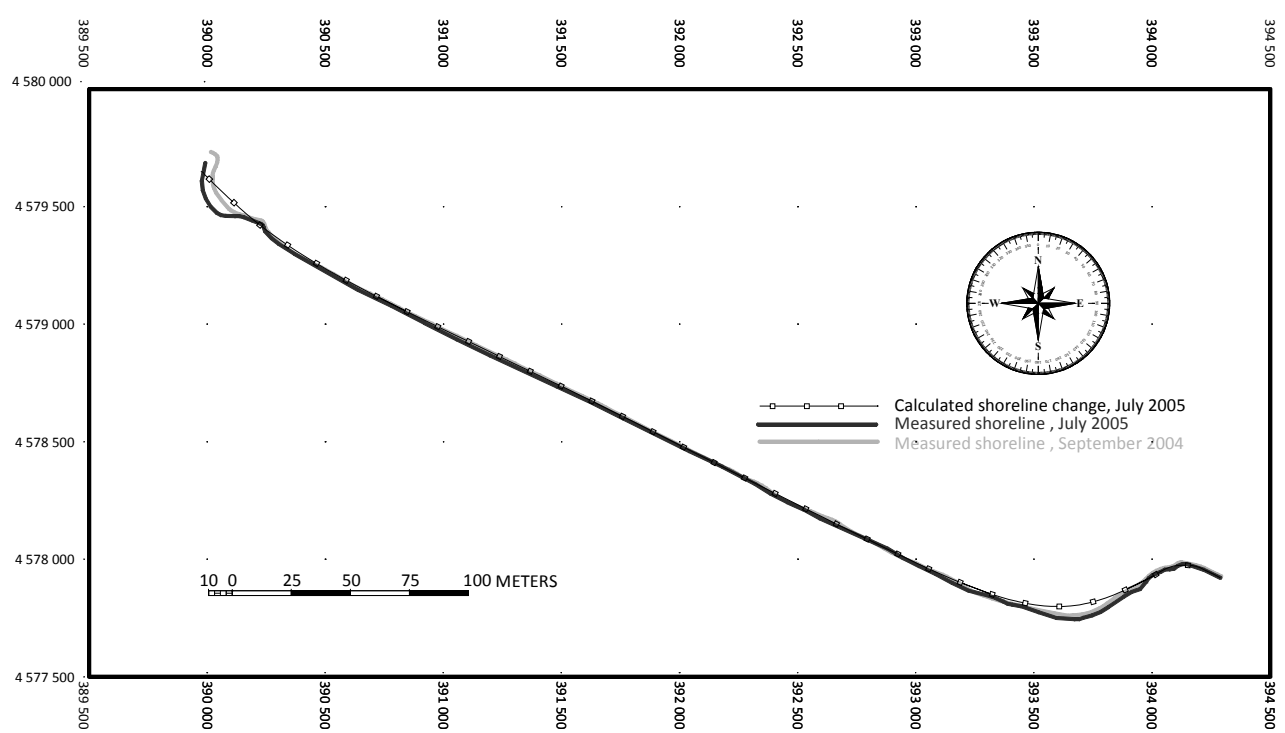

Fig. 5. Comparison of the coastline changes (measured vs. model output)

The study shows that the prediction of long term shoreline variation needs field work, analysis, observations and reliable and continuous wind, wave and current data. If there is 
no time history of shoreline or original shoreline measurement in any site, the remote sensing technology helps to monitor the shoreline.

The validation of the LITLINE model was performed with the field measurements initially. Karaburun coastline was measured with RTK-GPS between the years of 2004-2006. The RTK-GPS measurements provide accuracy of $2-3 \mathrm{~cm}$ horizontally. The coastline change between the years of 2004-2005 was simulated with LITLINE module and compared with RTK-GPS measurements. The model output showed that the model gave very reasonable results compared with in-situ measurement (Figure 5). Secondly, the coastline change obtained from LITLINE module was compared with coastline extracted from satellite image. IKONOS satellite images used in this study have radiometric solution of 11 bite and resolution of $1 \mathrm{~m}$. The compared results showed again that the simulated shoreline change with LITLINE module is very compatible with the extracted coastline using remote sensing technique (Figure 6).

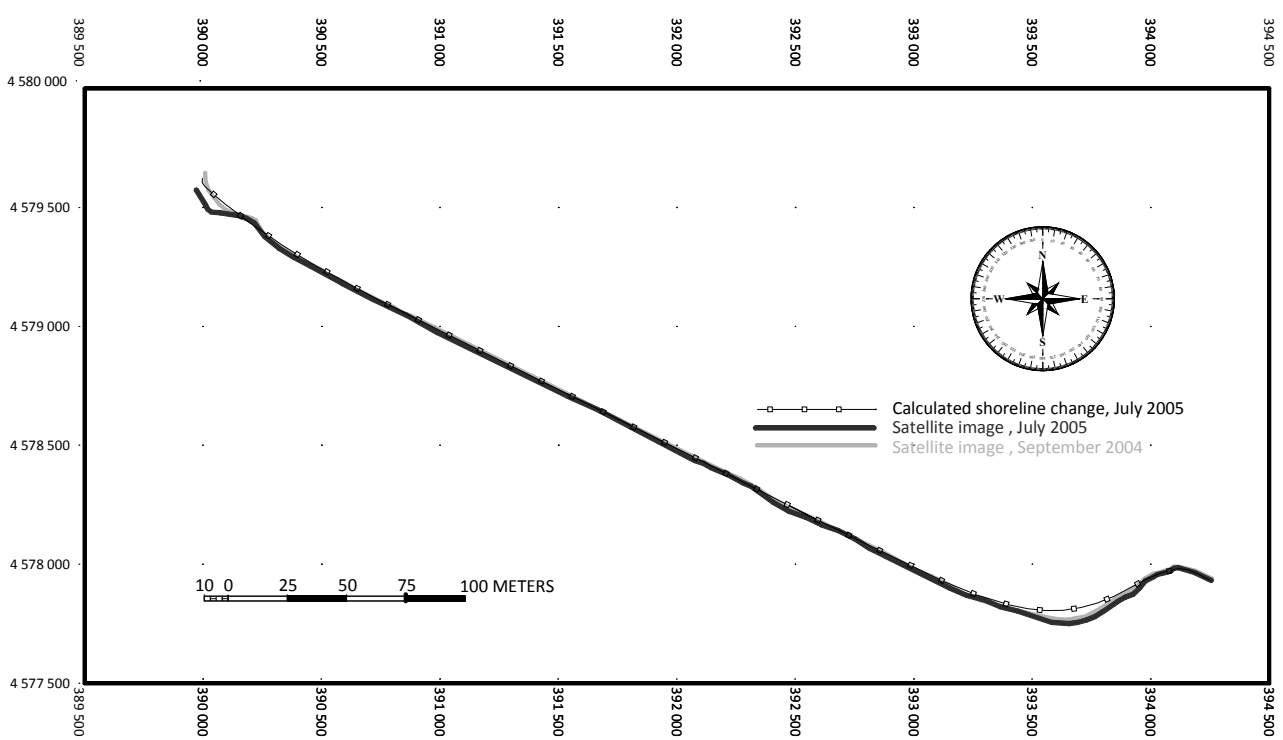

Fig. 6. Comparison of the coastline changes (extracted coastline from satellite image (IKONOS) vs. model output)

\section{References}

Ari, H.A., Yuksel, Y., Cevik, E.O., Guler, I., Yalciner, A.C. \& Bayram, B. (2007). Determination and control of longshore sediment transport: A case study. Ocean Engineering, 34 (2), pp 219-233

Bagnold, R.A. (1966). An approach to the sediment transport problem from general physics, Geological Survey Professional Papers, 422-1, Washington, USA

Bailard, J.A. (1984). A simplified model for longshore sediment transport, Proceedings of the 19th Coastal Engineering Conference, pp.1454-1470 
Bailard, J.A. \& Inman, D.L., (1981). An energetic bedload model for plane sloping beach: local transport, Journal of Geophysical Research, 86(C3), pp. 2035-2043

Bijker, E.W. (1971). Alongshore transport computations. Journal of Waterways, Harbors and Coastal Engineering Division, ASCE, Vol. 97, ww4, pp 687-701

Bayram, A., Larson, M., Miller, H.C. \& Kraus, N.C. (2001). Cross-shore distribution of longshore sediment transport: comparison between predictive formulas and field measurements, Coastal Engineering, 44, pp 79-99

Bayram, A., Larson, M. \& Hanson, H. (2007). A new formula for the total longshore sediment transport rate, Coastal Engineering, 54, pp 700-710

Carslaw, H. \& Jaeger, J. (1959). Conduction of Heat in Solids, Clarendon Press, Oxford, UK

Crank., J. \& Jaeger, J. (1975). The Mathematics of Diffusion, 2nd Edition, Clarendon Press, Oxford, UK

Dabees, M.A. (2000) Efficient Modelling of Beach Evolution, Ph.D. Thesis, Queen's University, Kingston, Ontario, Canada

Damgaard, J.S. \& Soulsby, R.L. (1997). Alongshore bed-load transport. Proceedings of the. 25th Int. Conf. Coastal Eng., Orlando, 3, pp. 3614-3627. ASCE

Dean, R.G., (1984). Principles of Beach Nourishment. In: P.D. Komar (Editor), CRC Handbook of Coastal Processes and Erosion. CRC Press, Boca Raton, Fla, pp. 217-232

Dean, R.G., (2002). Beach Nourishment: Theory and Practice, 118. World Scientific

Delft, (1993). UNIBEST User's Manual. Version 4.00. Delft Hydraulics Laboratory. The Netherlands

DHI (2008). LITPACK-An Integrated Modelling System for LITtoral Processes And Coasline Kinetics, Short Introduction and Tutorial, DHI Water and Environment

Fredsøe, J. \& Deigaard, R. (1992). Mechanics of Coastal Sediment Transport: Advanced Series on Ocean Engineering, World Science, Singapore

Grijm, W. (1961), Theoretical Forms of Shorelines. Proceedings of 7th Coastal Engineering Conf., ASCE: 197-202

Hanson, H. \& Kraus, N.C. (1991). Genesis: Generelized Model for Simulating Shoreline Change, CERC Report 89-19, Reprint, U. S. Corps of Eng., Vicksburg

Horikowa, K., (1988). Nearshore Dynamics and Coastal Processes: Theory, Measurement, and Predictive Models. University of Tokyo Press, Japan

Kamphuis, J.W. (1991). Alongshore sediment transport of sand, Journal of Waterway, Port, Coastal and Ocean Engineering, ASCE, Vol. 117 No.6, pp. 624-641

Kamphuis, J.W. (1999). Marketing Uncertainty, Proceedings of 5th Int. Conf. On Coastal and Port Eng. In Developing Countries, Capetown

Kamphuis, J. W. (2010). Introduction to Coastal Engineering and Management, 2nd Edition, World Scientific Publishing Co. Pte. Ltd.,ISBN-13 978-981-283-484-3, Singapore

Larson, M., Hanson, H. \& Kraus, N.C. (1987), Analytical Solutions of the One-Line Model of Shoreline Change, CERC Report 87-15, US Corps of Engineers, Vicksburg

Le Mehaute, B. \& Soldate, M. (1977). Mathematical Modelling of Shoreline Evolution, Misc. Rep. 77-10, US Corps of Engineers, Vicksburg

Longuet-Higgins, M.S., (1970). Longshore Currents Generated by Obliquely Incident Sea Waves, Journal of Geophysics Res., Vol.75, pp. 6778-6801

Pelnard-Considere, R. (1956). Essai de Theorie de l'Evolition des Formes de Rivage en Plages de Sable et de Galets, 4-ieme Journees de l'Hydraulique, Les engeries de la mer, Question III, Rapport No. 1 
Soulsby, R. (1997). Dynamics of Marine Sands, Thomas Telford, London

Szmytkiewicz, M., Biegowski, J., Kaczmarek, L.M., Okrój, T., Ostrowski, R., Pruszak, Z., Rózynsky, G. \& Skaja, M. (2000). Coastline Changes Nearby Harbour Structures: Comparative Analysis Of One-Line Models Versus Field Data, Coastal Engineering, Vol. 40., 199-139

USACE, (1984). Shore Protection Manual. Department of the Army, U.S. Corps of Engineers, Washington, DC 20314

Van der Velden, E.T.J.M. (1989). Coastal Engineering. vol.2, Delft TU

Van Rijn, L.C. (1984). Sediment transport: PartI: Bed load transport; Part II: Suspended load transport; Part III: Bed forms and alluvial roughness, Journal of Hydraulic Division, Vol.110, No.10, pp. 1431-1456; Vol.110, No.11, pp.1613-1641, Vol.110, No 12, pp.1733-1754

Van Rijn, L.C. (1993). Principles of sediment transport in rivers, estuaries and coastal seas, Aqua Publication, The Netherlands, Amsterdam

Walton, T.L., (1994). Shoreline Solution for Tapered Beach Fill. Journal of Waterway Port and Ocean Engineering, ASCE, 120(6): 651-655

Wang, P., Kraus, N.C. \& Davis, R.A., Jr. (1998). Total Rate of Longshore Sediment Transport in the Surf Zone: Field Measurements and Empirical Predictions, Journal of Coastal Research, 14(1), 269-283

Watanabe, A, Maruyama, T., Shimizu, T. \& Sakakiyama, T. (1986). Numerical prediction model of three-dimensional beach deformation around a structure, Coastal Engineering in Japan, JSCE, Vol.29, pp. 179-194

Watanabe, A. (1992). Total rate and distribution of longshore sand transport, Proceeding of the 23th Coastal Engineering Conference, pp.2528-2541

Wilson, K.C. (1989). Friction of wave induced sheet flow. Coastal Engineering, 12, 371-379 


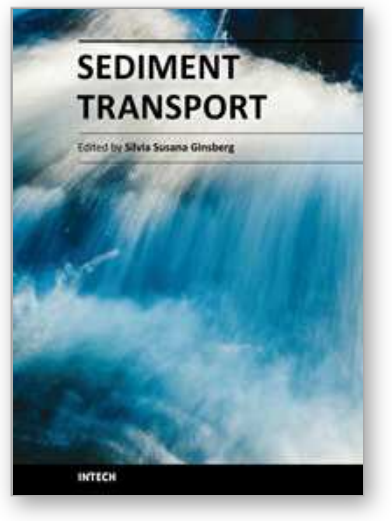

\author{
Sediment Transport \\ Edited by Dr. Silvia Susana Ginsberg
}

ISBN 978-953-307-189-3

Hard cover, 334 pages

Publisher InTech

Published online 26, April, 2011

Published in print edition April, 2011

Sediment transport is a book that covers a wide variety of subject matters. It combines the personal and professional experience of the authors on solid particles transport and related problems, whose expertise is focused in aqueous systems and in laboratory flumes. This includes a series of chapters on hydrodynamics and their relationship with sediment transport and morphological development. The different contributions deal with issues such as the sediment transport modeling; sediment dynamics in stream confluence or river diversion, in meandering channels, at interconnected tidal channels system; changes in sediment transport under fine materials, cohesive materials and ice cover; environmental remediation of contaminated fine sediments. This is an invaluable interdisciplinary textbook and an important contribution to the sediment transport field. I strongly recommend this textbook to those in charge of conducting research on engineering issues or wishing to deal with equally important scientific problems.

\title{
How to reference
}

In order to correctly reference this scholarly work, feel free to copy and paste the following:

H. Anıl Arı Güner, Yalçın Yüksel and Esin Ozkan Çevik (2011). Determination of Longshore Sediment Transport and Modelling of Shoreline Change, Sediment Transport, Dr. Silvia Susana Ginsberg (Ed.), ISBN: 978-953-307-189-3, InTech, Available from: http://www.intechopen.com/books/sedimenttransport/determination-of-longshore-sediment-transport-and-modelling-of-shoreline-change

\section{INTECH}

open science | open minds

\section{InTech Europe}

University Campus STeP Ri

Slavka Krautzeka 83/A

51000 Rijeka, Croatia

Phone: +385 (51) 770447

Fax: +385 (51) 686166

www.intechopen.com

\section{InTech China}

Unit 405, Office Block, Hotel Equatorial Shanghai No.65, Yan An Road (West), Shanghai, 200040, China 中国上海市延安西路65号上海国际贵都大饭店办公楼405单元 Phone: +86-21-62489820

Fax: $+86-21-62489821$ 
(C) 2011 The Author(s). Licensee IntechOpen. This chapter is distributed under the terms of the Creative Commons Attribution-NonCommercialShareAlike-3.0 License, which permits use, distribution and reproduction for non-commercial purposes, provided the original is properly cited and derivative works building on this content are distributed under the same license. 